\title{
THE CONCEPT OF WORK-LIFE BALANCE AND PRACTICAL APPLICATION FOR CUSTOMER SERVICES OF BANK
}

\author{
Dirga Lestari' ${ }^{1}$, Irsan Tricahyadinata1, Rahmawati Rahmawati' ${ }^{1}$, Dio Caisar \\ Darma $^{2 *}$, Siti Maria ${ }^{1}$, Ariesta Heksarini ${ }^{1}$ \\ ${ }^{1}$ Faculty of Economics and Business, Universitas Mulawarman, Indonesia \\ 2Sekolah Tinggi Ilmu Ekonomi Samarinda, Indonesia
}

\begin{abstract}
This paper aims to examine the work-life balance (WLB) standards applied by the Limited Company of Bank Central Asia (PT BCA) Samarinda branch and their impact on employee loyalty, job performance, and turnover intentions. Our targets for employees who work in customer services (CS). We collected the data through survey techniques, where the size of the informants was 340 samples. Multiple regression analyses indicate that the WLB policy has affected employee loyalty, turnover intentions, and job performance. Employee loyalty also plays an essential role in job performance and turnover intentions. Meanwhile, job performance has a significant effect on preventing turnover intentions. The fundamental difference to this finding lies in the escalation in the causality of the variables and is worth developing.
\end{abstract}

Keywords: Work-Life-Balance; Employee Loyalty; Turnover Intentions; Job Performance; Customer Service; Bank.

${ }^{*}$ Corresponding Author : diocaisar@stiesam.ac.id

DOI: $10.24252 /$ minds.v8i1.21121

ISSN-E: 2597-6990

ISSN-P: $2442-4951$

http://journal.uin-alauddin.ac.id/index.php/minds

Publisher: Program Studi Manajemen, Universitas Islam Negeri Alauddin Makassar 


\section{INTRODUCTION}

The company's continuity is determined by the company's strategy, which requires close collaboration from the internal aspects of a company. It carried this strategy out to support human resources through partnerships with outside parties and even take advantage of support by cross-country cooperation (Park, 2020).

The current attention to the concept of work-life balance (WLB) is undoubtedly the primary concern of various companies and individuals who work with many demands. There need to be logical consequences for the dramatic changes globally regarding the intensification of work, fragmentation of time, and demographic transformations. The massive need for the labor market, especially those of the female population, has been both a challenge and an opportunity for both men and women (Poelmans et al., 2008). They increasingly caught the current generation up in the job responsibilities of staying professional, while parents and their children also need intense attention.

As an initial view, Blood \& Wolfe (1960) integrated the non-influencing and segmented relationship between home and work. The independence perspective for applying the WLB concept concentrates on the workers in the office. Rincy \& Panchanatham (2014) describe a natural process expected in their workplace satisfaction and does not involve home and job segmentation. Family and work operate as inseparable bonds because there is no correlation and must separate family life and work life.

In organizations, employees are a vital resource, as they represent a significant investment in healthcare, recruiting, training, placements, job desks, salaries, and bonuses. Iqbal et al. (2015) specialize in organizational management to focus employees through measurable programs, work systems, job appraisals, and benefits packages according to their company policies.

A common problem with companies having loyal and satisfied employees is not enough. Martensen \& Grønholdt (2006) view that loyalists must show a real contribution and are confident with company value. Employee loyalty is insufficient to solve human resource management problems because a more holistic company requires concrete evidence of performance.

Campbell et al. (1993) differentiate performance based on aspects of productivity and effectiveness. Pritchard et al. (1988) refer to the effectivenessbased evaluation of performance results, including sales volume and financial value. Hours worked can also determine an individual's productivity success by considering costs and products built to achieve specific results. Job performance will undoubtedly result in many individual awards that will increase company value. In this situation, Locke (1970) prioritizes the most common terms of employment based on the level of entrepreneurship in the type of job through promotion, responsibility, recognition, salary, and praise.

To anticipate a crisis against WLB, employee loyalty, and work performance, companies also need to consider turnover intention related to 
organizational behavior in addition to company turnover. Employees who feel bored because they don't get the company's attention need a psychological process that involves the internal company to base decisions on turnover and change from time to time (Chen et al., 2020). Turnover is an integral part of the turnover intention process. Thus, the company's way of reducing concerns is through a framework that the two parties synergize.

Hom et al. (2017) and Liu et al. (2012) have predicted an increase or decrease in individual job satisfaction determined by behavior and turnover intentions and behaviors that exceed satisfaction statically.

Since the labor market demands change and professionalism, companies are shifting to empower female workers rather than men. Besides the more dominant number of female job seekers than men, women are also more serious at work, loyal, and rarely cause internal or external conflicts that cause complicated situations between employees and outside the company (Bujang et al., 2020 ).

PT Bank Central Asia (Tbk), known as BCA, is the largest private bank in Indonesia that prioritizes services and offers solutions to answer all the customers' financial needs (Syarif et al., 2017). With a vision and mission to reach the banking market in ASEAN, such as the Indonesian region, of course, they will continue to race and strive to optimize their performance for customers. We cannot separate companies engaged in the banking and service sector from employee retention as the key to their existence. Adaptation to market changes has made the PT BCA Samarinda branch more dependent on the best talents. Employee turnover at the PT BCA Samarinda branch happens frequently, but job dissatisfaction is more often at the marketing level than customer service (CS). CS plays a vital role through a mature recruitment process and leads to changes over time to achieve exemplary service quality. Therefore, the 'front guard' empowerment through CS continues to be carried out by the Samarinda branch of PT BCA through programs such as training, paying attention to their supporting facilities, incentives, and salaries that can satisfy CS.

This paper discusses WLB, employee loyalty, job performance, turnover intentions, and objectivity at the PT BCA Samarinda branch. Several steps are prepared to share the essential points. The first part is an introduction that explores the ideal expectations and phenomena. Second, a section presents theoretical support and an empirical review of relevant studies to construct hypotheses formed. In the third part, we show the procedures in data engineering. In the fourth section, empirical findings were presented, and it carried interpretations out. Finally, in the fifth part, the discussion is based on the main results, then concludes to see the limitations, thus contributing to the theoretical and practical aspects. There are notable differences between this study and previous studies. An interesting thing that needs to be highlighted is how the WLB concept plays a role in boosting employee loyalty, job performance, and turnover intentions in banking. We focus the sample size on 
all BCA branches in one city so that the accuracy of the data represents the responses of those who work as CS.

\section{THEORETICAL REVIEW}

Work-life balance (WLB)

Organizations that have implemented WLB policies are cautious about detecting their progress and as a benchmark or comparison against the progress of other organizations (Bardoel et al., 2008).

Clark (2000) termed the concept of WLB deeply implied for the organization, which comprises how well it can balance work responsibilities, non-work responsibilities, and the applied management pattern. Poelmans \& Caligiuri (2008) emphasized that the dominant responsibility of workers is very much determined outside of the organization, such as spiritual, social, and family roles. They often interpret the need for a balance point between work and life oppositely, ending with problems in life and work.

The fundamental theoretical approach that highlights the relationship between work and non-work is more determined by determining the interplay between life in the family and work. For this reason, Rincy \& Panchanatham (2014) emphasize that several theoretical approaches have suggested these two relationships, but there is a need for a clear separation integrated into the two domains. Even though there are differences between the theories reviewed, they are presented separately and differently. Interestingly, some views are more deserving of acceptance than others, so we need empirical evidence to answer each proportion and a comprehensive identification. At the very least, there will be a brief overview to discuss work and family relationships.

\section{Employee loyalty}

As a general term, loyalty is a sign of a person's devotion attached to a particular object. Britannica (1998) divides it into individuals or groups of people, where they have tasks, aspirations, and goals or hopes that want to be achieved. They can also express themselves in actions and thoughts to identify for the benefit of others in particular objects. Indirect employee loyalty can be determined by direct questions assuming whether they are working effectively for the organization. Stanton et al. (2003) concentrate on commitment and loyalty as more than just general behavior; but it requires a response from customers to employee performance.

Today, companies continue to strive to create loyal, committed, and dedicated strategies with significant achievements. For this reason, Bashaw \& Grant (1994) suggested that companies could increase their income. The other fundamental thing is, having loyal employees is not enough. From a company's point of view, it is essential to emphasize that those who faithfully contribute to its values are not satisfied (Jusriadi et al., 2021). From the perspective of human resource management, the development of general employee loyalty is necessary and holistic (Martensen \& Grønholdt, 2006). 


\section{Job performance}

Locke (1970) argues that reactions, dissatisfaction, and other emotional gratification are value responses. Employees can judge those situations that conflict with the standards of an object that are considered being beneficial.

Job performance is a series or variable often explored in studies connected and related to organizational behavior. In addition, Ratnasari et al. (2020) also highlighted that job performance is a central variable for the theory of organizational phenomena. The relevance of job performance stems from work orientation and affective, cognitive processes that are generalized to one's current employer and occupation in a particular field.

Extrapolation by Schuler (1989) and Locke (1969) concluded that job performance is a significant function of worker satisfaction, and this will lead to the achievement of individual job values without overriding other values. The emergence of "expectancy theory" offers a broad and similar viewpoint for assessing emotional and explicit relationships to follow up on employee job performance for organizations (Vroom, 1964).

\section{Turnover intention}

Directly, Chen et al. (2011) observed that most turnover theories suggest that job satisfaction is negatively related to employees' intention to quit their job. It will have a positive impact on actual turnover. Regardless, voluntary layoffs or employee turnover. Over the past century, this has attracted the attention of practitioners and academics to investigate turnover intention. It focused attention on documenting how employees stopped asking for raises and bonuses (Hom \& Griffeth, 1995).

The work environment and prolonged work stress can influence why someone triggers the desire to move and leave the organization. They certainly lose work motivation, so there needs to be further action from their superiors to prevent this (Hom et al., 2017).

\section{Empirical review and hypothesis development}

WLB is the ability of individuals to carry out good functions and minimize conflicts between individual roles at work and in the family to get benefits and satisfaction when carrying out their roles. Hawa \& Nurtjahjanti (2018) found that WLB and team member loyalty have a positive correlation.

WLB supported job retention and attractiveness can stimulate team member engagement in the company. Westman et al. (2009) interpreting WLB as the extent to which individuals can feel satisfied and involved in an excellent psychological and time, where their roles personally and in work-life do not occur in the conflict between the two positions.

High work demands will lead to stress levels, so that life at work and life in a family environment is not balanced due to increased work demands leading to higher stress levels. With WLB policies, it can positively impact and reduce absenteeism on turnover intentions and employee productivity (Malik et 
al., 2010). Every organization tries to avoid turnover intentions because this phenomenon has a negative impact, and of course, there are significant cost consequences. Laksono \& Wardoyo (2019) emphasize that WLB has contributed to reducing turnover intentions.

Those who experience repeated absences, low morality, and frequent changes in staff intensity because of turnover intentions will have lower work quality and productivity levels (Ötken \& Erben, 2013).

Mendis \& Weerakkod (2017) and Kithae \& Keino (2016) have investigated the relationship between WLB and work performance. As a result, WLB has a significant correlation with the performance of employees at senior and executive levels. On the other hand, Ardiansyah \& Surjanti (2020) concluded that the relationship between WLB and work performance is insignificant.

Performance is the ability of employees to do a job with a specific strategy that leads to the organization and to achieve common goals. Performance is a form of realization of the achievement of the company's vision and mission. Performance is also a measuring tool for each work unit, group, and individual to achieve or even exceed the production targets that have been previously set (Mendis \& Weerakkody, 2017; Metin \& Asli, 2018). Therefore, we predict that:

H1 (a) - WLB affects team member loyalty positively.

H1 (b) - WLB affects turnover intentions negatively.

H1 (c) - WLB affects job performance positively.

According to Alfiyah (2016), the decline in employee work performance is caused by a low level of loyalty. Job desks or inaccurate placement of employees can also cause these possibilities based on their fields, thus hindering their productivity, especially for those with high job satisfaction. This adversity resulted in employees' laziness.

A similar argument is also in line with Preko \& Adjetey's (2013) findings if someone's loyalty positively affects their performance. Being influenced by the relationship between leadership style, work results, colleagues, and personal development can determine employee loyalty to improve their performance. In a study showing the effect of team member loyalty on job performance, Faradila et al. (2020) presented their findings with significant results.

When the intention and motivation to work immediately disappear, they will be lazy to work and think about turnover intentions. One factor that supports turnover is team member loyalty. When they are in a condition or are lazy to start work, disobeying company regulations, and are less responsible for employment, employees will get bored. If they do not meet their needs based on their wishes, they feel uncomfortable at work. This factor is also considered to carry out turnover intentions (Hafni \& Sari, 2019).

Dwipayoga \& Adnyani (2013) focused their study on employee loyalty and employee turnover intention, where they prioritized staying in the company, feeling belonging, self-dedication, serious business, and great concern as critical dimensions for them not to make a turnover intention. Therefore, we predict that:

H2 (a) - Employee loyalty affects job performance positively. 


\section{H2 (b) - Employee loyalty affects turnover intentions negatively.}

If the employees are at maximum work performance, they can be resultoriented, planning, and excellent task organizing (Murphy, 2008). If they have achieved all of this, then two choices will determine their future, i.e., stay or turnover. Two vital aspects can evaluate an individual's work performance, namely process and outcome. Zimmerman \& Darnold (2009) discuss these two aspects, where the process aspect is a specific pattern of activity when an employee is working, while the outcome aspect determines the goals and consequences for the work done. Biron \& Boon (2013) assess that work performance is closely related to turnover intention. When they are in low work performance, the turnover intention is high and vice versa; if the employee's work performance is high, the turnover intention is reduced. Therefore, we predict that:

H3 - Job performance affect turnover intentions negatively.

\section{METHODOLOGY}

\section{Sample size and demarcation}

This study conducts a field survey-based research and is paired with qualitative interviews with informants who know for sure about the conditions that occur (e.g., Hernaus et al., 2020; Ikbal et al., 2020a, b). The sample includes employees who work for PT BCA in Samarinda City. For more details, we focused the selection on those who occupy the CS position. The sample has been determined to cover the entire population and divided into regional groups (Banerjee \& Chaudhury, 2010). We got the data through PT BCA Indonesia (center) regarding the CS employees. When referring to the minimum sample size with an error margin of $5 \%$ and $1 \%$, a 500 population results in a 217 sample (Adam, 2020). This study has met the sample size with 340 samples distributed to CS at PT BCA in all Samarinda's branches. There are ten PT BCA locations in Samarinda, spread across ten branches or per sub-district (Palaran, Samarinda Ilir, Samarinda Kota, Sambutan, Samarinda Sebarang, Loa Janan Ilir, Sungai Kukung, Samarinda Ulu, North Samarinda, and Sungai Pinang). Evenly distributed, each unit will represent 34 samples. We concentrate each researcher in two locations (68 informants) for the study's specification.

The data intended are primary data with questionnaire distribution techniques. In the first step, we need to make observations to review the location. Second, preparations must be well planned so that each researcher gets his assignment to conduct surveys and interviews with each object, where one researcher reaches two things or branches of PT BCA. Furthermore, items in the form of work stationery, recorders, mobile phones, questionnaires, and of course, pay attention to the health protocols implemented by the local government during Covid-19 by always wearing masks, maintaining distance, and washing hands. The survey implementation period is from June 2020 to November 2020. To ensure validity and avoid questions that create biased 
perceptions, we need to be careful and ask the informants in detail so that nothing is empty or not filled.

\section{Procedures and variables}

A Likert scale determines the procedure for assessing perceptions with five points (very important - 5, important - 4, moderately important - 3, not important - 2, and very not important - 1). It will then ask the informants several essential questions regarding the variables we have designed in Table 1.

Table 1. Specifications on Variables and Items

\begin{tabular}{|c|c|c|}
\hline Variables & Dimensions & Actual reference \\
\hline WLB & $\begin{array}{l}\text { Stress, exhaustion, time, family, and } \\
\text { responsibilities }\end{array}$ & Živčicová et al. (2017) \\
\hline Employee loyalty & $\begin{array}{l}\text { Belongingness, job involvement, and } \\
\text { organizational commitment }\end{array}$ & Rajput et al. (2016) \\
\hline Job performance & $\begin{array}{l}\text { Task performance, interpersonal } \\
\text { citizenship, organizational } \\
\text { citizenship, and job education }\end{array}$ & $\begin{array}{l}\text { Maroofi \& Navidinya } \\
\text { (2011) }\end{array}$ \\
\hline Turnover intentions & $\begin{array}{l}\text { Justice perceptions, employees } \\
\text { affective, cognitive states, behavioral } \\
\text { employee, and job satisfaction }\end{array}$ & Bu et al. (2011) \\
\hline
\end{tabular}

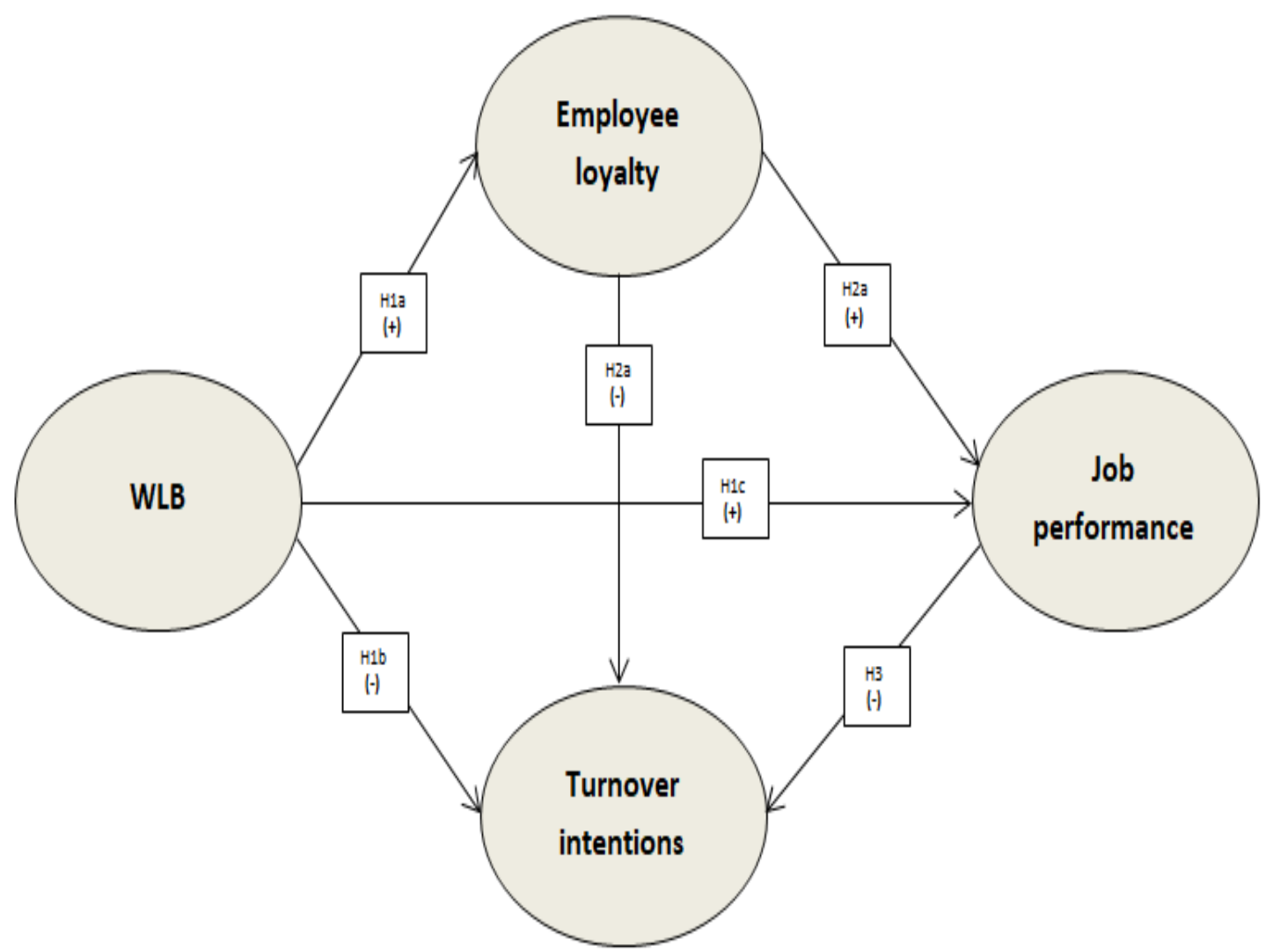

Figure 1. Concept and Expected Signs 
Seventeen items cover these four variables and have their respective benchmarks. Team member loyalty has three dimensions. While there are four dimensions in job performance, the turnover intentions and WLB have a similar total dimension, namely five dimensions. These variables have different goals based on their role. In hypothesis-1a, hypothesis-1b, and hypothesis-1c, WLB is the independent variable, and employee loyalty, turnover intentions, and job performance are the dependent variables. In hypothesis- $2 a$ and hypothesis- $2 b$, employee loyalty (independent variable) explains its relationship to the dependent variable, in this case, represented by job performance and turnover intentions. Then, from hypothesis-3, turnover intentions as the dependent variable influenced by the independent variable, namely job performance. Thus, Figure 2 summarizes the causality relationship between the variables.

Interpretation analysis

Since it supports the study by quantitative data with six proposed hypotheses, we only focus on the direct effect. We carried multiple linear regression analyses to evaluate each variable's relative contribution (Kahya, 2009). Additional software such as Microsoft Excel for the tabulation of sample demographic characteristics and analysis testing via SPSS. There are three data processing criteria before the conclusion, including descriptive statistics comprising mean, standard deviation (SD), Person correlation. The next session covers the feasibility of a questionnaire with its reliability and coefficient of determination (R2), while a multiple regression model is used to present the results of the hypothesis.

SPSS tested reliability analysis with the criteria for the reliability coefficient (Cronbach's a) to be at least above 0.60 (Podsakoff et al., 2000; Shore et al., 1990). Consistency in this test will see whether an item has a strong correlation with others or vice versa. On the Pearson correlation, Wijayanti et al. (2020) confirm that the interval is in the range $0-1$. The six classifications of this correlation are 1 (perfect correlation), 0.75 - 0.99 (very strong correlation), 0.50 0.75 (strong correlation), 0, 25 - 0.50 (weak correlation), $0.00-0.25$ (very weak correlation), and 0 (no correlation).

\section{RESULTS}

Informants' explanations based on gender, age, marital status, educational background, and duration of work as CS at PT BCA Samarinda were quite diverse. Table 2 presents an exciting sample demographics, where females than males occupy jobs in CS positions. From the age interval, employees aged 19 years - 30 years are very dominant because we classified the age range as productive age. Some employees are married, but some are unmarried, and the rest are divorced. With many undergraduate and high school graduates, the average working time also determines the experience of employees in the workplace, where most have worked for two years - 4 years, and this is a bright prospect for the company's sustainability. 
Table 2. Details of the Sample

\begin{tabular}{|l|l|l|l|}
\hline \multicolumn{2}{|c|}{ Characteristic factors } & Frequency & Percentage \\
\hline Gender & - Male & 73 & 21.47 \\
& - Female & 267 & 78.53 \\
\hline Age & $-19-24$ & 131 & 38.53 \\
& $-25-30$ & 94 & 27.65 \\
& $-31-36$ & 40 & 11.76 \\
& $-37-42$ & 57 & 16.76 \\
& $-43+$ & 18 & 5.29 \\
\hline Status & - Married & 166 & 48.82 \\
& - Unmarried & 115 & 33.82 \\
& - Others & 59 & 17.35 \\
\hline Education & - High school & 102 & 30.00 \\
& - University & 189 & 55.59 \\
& - Master & 38 & 11.18 \\
\hline Tenure & - Ph.D & 11 & 3.24 \\
& - Less than two years & 5 & 1.47 \\
& - 2-4 years & 254 & 74.71 \\
& - 5-7 years & 67 & 19.71 \\
\hline
\end{tabular}

Source: field identification.

Table 3. Scores for Mean, SD, and Pearson Correlation

\begin{tabular}{|l|l|l|l|l|l|l|}
\hline \multicolumn{1}{|c|}{ Variables } & \multicolumn{1}{c|}{ Mean } & \multicolumn{1}{c|}{ SD } & \multicolumn{1}{c|}{$[\mathbf{1}]$} & [2] & [3] & [4] \\
\hline WLB & 3.231 & 0.364 & 1 & & & \\
\hline Employee loyalty & 3.523 & 0.819 & $0.644^{* *}$ & 1 & & \\
& & & $(0.000)$ & & & \\
\hline Job performance & 4.310 & 0.484 & $0.826^{*}$ & $0.572^{*}$ & 1 & \\
& & & $(0.000)$ & $(0.000)$ & & \\
\hline $\begin{array}{l}\text { Turnover } \\
\text { intentions }\end{array}$ & 2.248 & 0.791 & $0.438^{* *}$ & $0.293^{* *}$ & $0.475^{*}$ & 1 \\
\hline
\end{tabular}

Note: ${ }^{*} \mathrm{p}<0.05$, and ${ }^{* *} \mathrm{p}<0.01$.

With 95\% and 99\% degrees of freedom, it got Person correlation to show the level of correlation coefficient in each relationship between variables. It illustrates the strong correlation by the one-way relationship between job performance and WLB. There is a weak correlation between turnover intentions and employee loyalty in two directions. The scores for mean and SD were highest on job performance and employee loyalty, while turnover intentions explained the smallest mean, and WLB held the lowest SD record. We summarize the overall descriptive statistics in Table 3. 
Table 4. Calculations for Cronbach's alpha (CA) and Determination $\left(\mathrm{R}^{2}\right)$

\begin{tabular}{|c|c|c|c|}
\hline Var. & Dimensions & $\mathbf{R}^{2}$ & a \\
\hline WLB & $\begin{array}{l}\text { - Right now, I feel stressed } \\
\text { - Work leaves me exhausted } \\
\text { - Too much time is wasted at work } \\
\text { - Family is a burdening factor in my mind } \\
\text { - Responsibilities at work and family are } \\
\text { imbalanced }\end{array}$ & 0.736 & $\begin{array}{l}0.654 \\
0.786 \\
0.751 \\
0.742 \\
0.725\end{array}$ \\
\hline EL & $\begin{array}{l}\text { - My emotional need is a sense of belonging to } \\
\text { work } \\
\text { - I got involved at work } \\
\text { - My colleague has an excellent organizational } \\
\text { commitment }\end{array}$ & 0.852 & $\begin{array}{l}0.665 \\
0.823 \\
0.624\end{array}$ \\
\hline JP & $\begin{array}{l}\text { - My job desk is per the performance results } \\
\text { - I work in an interpersonal culture } \\
\text { - Without assistance, I took care of this job } \\
\text { - There is special training in certain areas of work }\end{array}$ & 0.737 & $\begin{array}{l}0.873 \\
0.865 \\
0.871 \\
0.882\end{array}$ \\
\hline $\mathrm{TI}$ & $\begin{array}{l}\text { - The company acts reasonably through extra } \\
\text { wages and bonuses } \\
\text { - Employee emotional involvement is } \\
\text { indispensable in the workplace } \\
\text { - Fellow employees try always to remind job } \\
\text { desks } \\
\text { - Employee behavior determines the development } \\
\text { of organizational culture } \\
\text { - I find new things and get satisfied when I finish } \\
\text { my job }\end{array}$ & & $\begin{array}{l}0.861 \\
0.872 \\
0.874 \\
0.859 \\
0.893\end{array}$ \\
\hline
\end{tabular}

Source: field identification.

Table 4 accommodates the assumptions that all dimensions must meet in the four variables. The informant said what was fully accountable, open, and had its identity to maintain the emotional bond between employees and superiors. In this study, the $\mathrm{R}^{2}$ value is very valid because it is almost perfect. It can prevent this if the WLB's determination of employee loyalty, turnover intentions, and job performance reaches $73.6 \%$. In the relationship between employee loyalty and job performance and turnover intentions, a determination coefficient of $85.2 \%$ got, and this is also the highest determination compared to other relationships. Validity further clarifies the relationship between job performance and pretty successful turnover intentions. The $\mathrm{R}^{2}$ of $73.7 \%$ in these two factors shows that there is an interrelated pattern.

The score for CA, too, is interesting to review. As the display of the SPSS output, we find that the seventeen-dimensional attainment of the four variables is actual because $a>0.60$. This result is inseparable from the success of all the questions answered by the informants with a competent understanding. An immense a value for Q-17 at "TI" and the lowest with the lowest a is "EL," precise at Q-8. 
Table 5. Empirical Estimation

\begin{tabular}{|l|c|c|c|c|c|l|}
\hline \multicolumn{1}{|c|}{ Hypothesis } & $\boldsymbol{\beta}$ & SE & Level & t-statistic & Prob. & \multicolumn{1}{c|}{ Sign } \\
\hline $\begin{array}{l}\text { H1.a: WLB -> } \\
\text { EL }\end{array}$ & 0.606 & 0.043 & $* *$ & 5.065 & $0.000<0.01$ & Positive \\
\hline $\begin{array}{l}\text { H1.b: WLB -> } \\
\text { TI }\end{array}$ & -0.012 & 0.154 & $* *$ & -0.155 & $0.093>0.01$ & Negative \\
\hline $\begin{array}{l}\text { H1.c: WLB -> } \\
\text { JP }\end{array}$ & 0.515 & 0.014 & $*$ & 1.230 & $0.041<0.05$ & Positive \\
\hline H2.a: EL -> JP & 0.273 & 0.102 & $*$ & 2.925 & $0.036<0.05$ & Positive \\
\hline H2.b: EL -> TI & -0.284 & 0.270 & $* *$ & -3.082 & $0.066>0.01$ & Negative \\
\hline H3: JP -> TI & -0.957 & 0.242 & $*$ & -1.841 & $0.057>0.05$ & Negative \\
\hline
\end{tabular}

Note: $\beta$ (Standardized coefficient), Standard error (SE), ${ }^{*} \mathrm{p}<0.05$, and ${ }^{* *} \mathrm{p}<0.01$.

Based on the prediction, seven hypotheses have been declared "accepted" with the suitability of the respective beta coefficients $(\beta)$. In its partial effect (one-way relationship), employee loyalty to job performance is the most dominant influence, where the probability is the lowest, and the $t$-value is the highest compared to the other three relationships. There was a direct two-way effect $(p<0.01)$ in all three lines, involving WLB and team member loyalty, which had the most dominant relationship, and the t-value, which was also the highest (see Table 5).

The expectations in this experiment have been successful because the residue in all three models is relatively small. The evaluations for the first model, the second model, and the third model are $26.4 \%, 24.8 \%$, and $26.3 \%$, which tolerate confounding factors or not explained in H1 (WLB on team member loyalty, turnover intentions, and job performance), H2 (employee loyalty with job performance and turnover intentions), and $\mathrm{H} 3$ (job performance against turnover intentions).

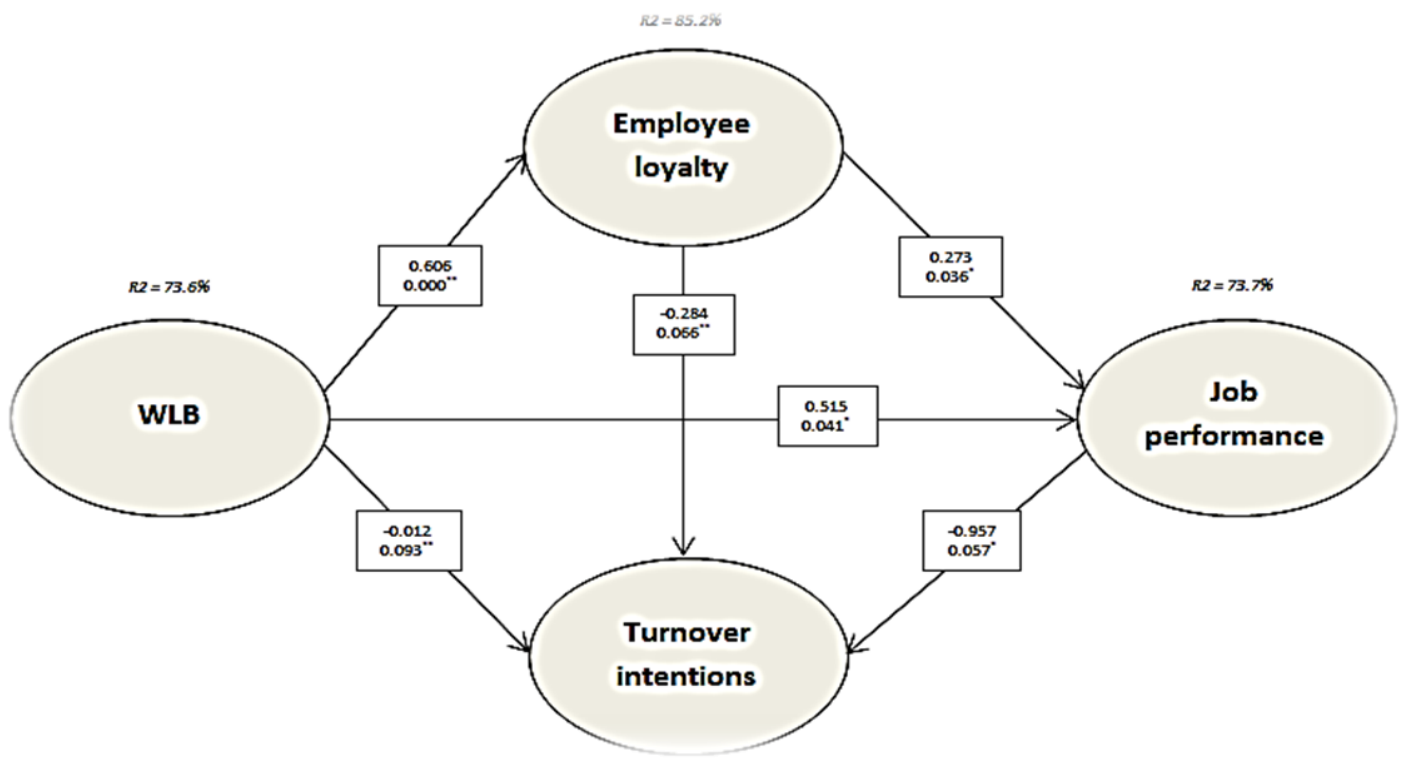

Figure 2. Regression Model

Note: ${ }^{*} \mathrm{p}<0.05$, and ${ }^{* *} \mathrm{p}<0.01$. 
On job performance, employee loyalty has a significant effect $(p<0.05)$ and is not substantial for turnover intentions $(p>0.01)$. Figure 3 shows that we can derive turnover intentions through job performance because the probability level is higher than 0.05 .

\section{DISCUSSION}

This paper seeks to investigate the concept of WLB concerning employee loyalty, job performance, and turnover intentions for PT BCA in all parts of Samarinda City. We highlight six findings that provide evidence that WLB can strengthen employee loyalty and job performance but that WLB also serves to prevent turnover intentions. Another critical point is that employee loyalty can improve job performance and employee loyalty also contains turnover intentions. Turnover intentions will decrease if there is an increase in job performance.

Job performance plays a crucial role in reducing turnover intentions for PT BCA employees compared to WLB and employee loyalty. Most likely, the company has paid attention to them optimally. Policies or standard operating procedures (SOPs) have adapted local wisdom and Indonesian culture that prioritizes guarantees in education, health aspects, and of course, employee career development.

In another discussion, WLB is the only factor that can increase employee loyalty. After that, if we compare the role of WLB and employee loyalty to job performance, it is WLB that has the most excellent effect. Each employee has their respective abilities according to the work environment, the expertise occupied, and the field placement. Especially for CS in the banking world, they are trained to serve customers who want to open new accounts, give satisfaction, tidy up administration, and internal audit. As the front guard, CS has a heavy role indirectly monitoring the continuity of the workplace.

Given the weaknesses of studies that use a survey approach, it is hoped that other researchers in the future will consider data collection techniques with different types of samples. In addition, the multiple regression model is still limited to projecting an indirect (mediation) relationship. The accuracy of variables and items continuously adapts not only to one area in a particular workplace but can be broadly expanded across elements or several substances in an object.

It is not easy for PT BCA to open recruitment outside the planned agenda. Their passions lead to how this strategy execution affects the CS to serve customers. It must be consistent and continuously strived to get a positive "image" in customers' eyes. They minimize costly, energy-consuming, and timeconsuming moments to find new employees because turnover intentions are not ideal for business consideration.

The point of view of Jaharuddin \& Zainol (2019) discusses the relationship between WLB and turnover intention, employee performance, and job performance. In practice, WLB is very important for the organization to ensure 
the welfare of employees and support them to remain in harmony with their family members. Another reference point lies in the ambition experiment by Javed et al. (2014), which shows a significant positive relationship between job loyalty and employee performance. Meanwhile, there is no meaningful negative relationship between job loyalty to turnover intention. Job satisfaction depends on the success of a productive relationship between management and employees.

The consequences of conflict of interest at work have implications for a decrease in individual performance and will form small groups that trigger tensions (Terek et al., 2018). When a dispute between one employee and another employee gets bigger, then one of them has the opportunity to leave the workplace. These incidents must be avoided, and there needs to be productivity in teamwork. This finding is also relevant from the study of Alferaih (2017), which provides an understanding of how job performance affects employee turnover intention and organizations can control turnover through wise supervisors. Underperforming employees are more likely to stop maintaining job satisfaction and have a preference to leave. Generally, it is not planned, and those who perform well can control job satisfaction.

\section{FURTHER STUDY}

This paper certainly has significant implications for practical and theoretical development. Mission competently must refer to which dimensions or indicators are weak in the variables. In WLB, the quantity of work is the crucial factor that makes employees tired, so the company needs to pay attention. They like their job as CS and don't feel pressured. Second, team involvement in each employment is crucial in the employee loyalty variable compared to organizational commitment. It provides a reference for companies to evaluate the work output thoroughly. Third, work education is a dimension that largely determines job performance, and formal and informal communication between employees so far has been well established. The company will also continue to carry out special education to CS intensively and periodically because new things continue to develop along with technological modernization. Fourth, over the course of the observation, we also found essential insights into the factors influencing turnover intentions. Of the five questions in the questionnaire for the turnover intentions variable, general workplace satisfaction is necessary for obtaining productivity. When compared with other components, they said the behavior of fellow employees to be quite good. That way, the focus is on employee satisfaction. The company needs to pay attention to generate motivation, for example, through programs that specialize in CS being involved in game shows, educational-based entertainment, and the latest agendas that can create good emotional and intellectual bonds.

The reflection that becomes a fundamental question is how significant the role of the leaders and directors of PT BCA in each branch is to follow up this discovery with a transformation in the WLB concept. Drastic changes certainly actualize employee expectations to get significant work performance and 
loyalty. A charismatic and democratic type of leader should listen to employee complaints more to reduce friction in the workplace and keep them from turning over intentions.

The involvement and retention of these findings provide theoretical recommendations, including those of great relevance to be presented by other researchers with different concepts, methods, and analyses to characterize the conceptualization of WLB in large companies or large reputable banks.

\section{ACKNOWLEDGMENT}

We need to appreciate the outstanding performance of the authors and data support from the management of PT BCA (Samarinda branch) for providing the time and opportunity. The authors declare no conflict of interest in this paper and handle the development of public knowledge. In addition, we are also grateful to the 'Jurnal Minds: Manajemen, Ide, dan Inspirasi' as a space to expand studies in management, especially for problems surrounding human resources, social sciences, and organizations.

\section{REFERENCES}

Adam, A. M. (2020). Sample size determination in survey research. Journal of Scientific Research and Reports, 26(5), 90-97. https:/ / doi.org/10.9734/jsrr/2020/v26i530263.

Alferaih, A. (2017). Developing a conceptual model to measure talent's turnover intention in tourism organizations of Saudi Arabia. International Journal of Organizational Analysis, 25(1), 2-23. https://doi.org/10.1108/IJOA-10-20140803.

Alfiyah, S. E. (2016). Work motivation, loyalty, and employee quality on the performance of employees of PT Varia Usaha Gresik. BISMA - Bisnis dan Manajemen, 8(2), 144-155. https:/ / doi.org/10.26740/bisma.v8n2.p144-155.

Ardiansyah, C. A., \& Sujanti, J. (2020). Effect of work life balance on employee performance through organizational commitment to the employees of PT Bhinneka Life Indonesia, branch Surabaya. Jurnal Ilmu Manajemen, 8(4), 1211-1221.

Bardoel, E. A., De Cieri, H., \& Santos, C. (2008). A review of work-life research in Australia and New Zealand. Asia Pacific Journal of Human Resources, 46(3), 316-333. https://doi.org/10.1177/1038411108095762.

Banerjee, A., \& Chaudhury, S. (2010). Statistics without tears: Populations and samples. Industrial Psychiatry Journal, 19(1), 60-65. https:/ / doi.org/10.4103/0972-6748.77642.

Bashaw, R. E., \& Grant, E. S. (1994). Exploring the distinctive nature of work commitments: Their relationships with personal characteristics, job performance, and propensity to leave. Journal of Personal Selling $\mathcal{E}$ Sales Management, $14(2)$, 41-56. https:// doi.org/10.1080/08853134.1994.10753984. 
Biron, M., \& Boon, C. (2013). Performance and turnover intentions: A social exchange perspective. Journal of Managerial Psychology, 28(5), 511-531. https:// doi.org/10.1108/JMP-09-2011-0054.

Blood, R. O., Jr., \& Wolfe, D. M. (1960). Husbands and wives: The dynamics of family living. New York: Free Press Glencoe.

Britannica, E. (1998). The definition of loyalty. Accessed from http://www.web2010.com.marceric/archive/arc3.htm [28-03-2021].

Bu, N., McKeen, C. A., \& Shen, W. (2011). Behavioural indicators of turnover intention: The case of young professionals in China. The International Journal of Human Resource Management, 22(16), 3338-3356. https:// doi.org/10.1080/09585192.2011.561214.

Bujang, R., Kasuma, J., Isnin, N., Neging, P., Hassan, A. N., Darma, D. C., \& Kuleh, Y. (2020). Relationship between client satisfaction, service quality and client perception towards the effectiveness of client consultation services. International Journal of Psychosocial Rehabilitation, 24(03), 5648-5656. https:// doi.org/10.37200/IJPR/V24I3/PR2021164.

Campbell, J. P., McCloy, R. A., Oppler, S. H., \& Sager, C. E. (1993). A theory of performance. In Schmitt, C. W and Borman, W. C (eds), Personnel Selection in Organizations. San Francisco: Jossey Bass, pp. 35-70.

Chen, G., Ployhart, R. E., Thomas, H. C., Anderson, N., \& Bliese, P. D. (2011). The power of momentum: A new model of dynamic relationships between job satisfaction change and turnover intentions. Academy of Management Journal, 54(1), 159-181. https:/ / doi.org/10.5465/ AMJ.2011.59215089.

Chen, K., Zhang, Y., Zhu, G., \& Mu, R. (2020). Do research institutes benefit from their network positions in research collaboration networks with industries or/and universities?. Technovation, 94-95, 102002. https:/ / doi.org/10.1016/j.technovation.2017.10.005.

Clark, S. C. (2000). Work/family border theory: A new theory of work/family balance. Human Relations. 53(6), 747-770. https:/ / doi.org/10.1177/0018726700536001.

Dwipayoga, K. S., \& Adnyani, I. G. (2013). The influence of physical work environment, leadership and compensation on employee loyalty at PT Gino Valentino Bali. E-Jurnal Manajemen, 2(2), 137-152.

Faradila, N., Heksarini, A., \& Darma, D. C. (2020). Antecedents that affect job satisfaction and employee performance. Saudi Journal of Business and Management Studies, 5(6), 293-302. https:// doi.org/10.36348/sjbms.2020.v05i06.001.

Hafni, L., \& Sari, D. D. (2019). Analysis effect of compensation, job stress, and employee loyalty on the turnover intention of employees PT Wiradjaja Prima Kencana, Pekanbaru. Procuratio: Jurnal Ilmiah Manajemen, 7(1), 55-66.

Hawa, M. A., \& Nurtjahjanti, H. (2018). Relationship between work-life balance with the employee loyalty PT Hanil Indonesia in Boyolali. Jurnal Empati, $7(1), 424-429$.

Hernaus, T., Konforta, M., \& Sitar, A. S. (2020). A multi-informant assessment of organizational agility maturity: An exploratory case analysis. Dynamic 
Relationships Management Journal, 9(2), 85-104. https:/ / doi.org/10.17708/DRMJ.2020.v09n02a05.

Hom, P. W., \& Griffeth, R. W. (1995). Employee turnover. Cincinnati, OH: SouthWestern College Publishing.

Hom, P. W., Lee, T. W., Shaw, J. D., \& Hausknecht, J. P. (2017). One hundred years of employee turnover theory and research. Journal of Applied Psychology, 102(3), 530-545. https:/ / doi.org/10.1037/ apl0000103.

Ikbal, M., Irwansyah, I., Paminto, A., Ulfah, Y., \& Darma, D. C. (2020a). Financial intelligence: Financial statement fraud in Indonesia. Journal of Intelligence Studies in Business, 10(3), 80-95. https:// doi.org/10.37380/jisib.v10i3.640.

Ikbal, M., Irwansyah, I., Paminto, A., Ulfah, Y., \& Darma, D. C. (2020b). Explores the specific context of financial statement fraud based on empirical from Indonesia. Universal Journal of Accounting and Finance, 8(2), 29-40. https:// doi.org/10.13189/ ujaf.2020.080201.

Iqbal, A., Tufail, M. S., \& Lodhi, R. N. (2015). Employee loyalty and organizational commitment in Pakistani organizations. Global Journal of Human Resource Management, 3(1), 01-11.

Jaharuddin, N. S., \& Zainol, L. N. (2019). The impact of work-life balance on job engagement and turnover intention. The South East Asian Journal of Management, 13(1), 106-118. https:/ / doi.org/10.21002/ seam.v13i1.10912.

Javed, M., Balouch, R., \& Hassan, F. (2014). Determinants of job satisfaction and its impact on employee performance and turnover intentions. International Journal of Learning and Development, 4(2), 120-140. https://doi.org/ 10.5296/ijld.v4i2.6094.

Jusriadi, E., Syafaruddin, S., \& Rusydi, M. (2021). Human capital development of research staff through self-leadership, teamwork management, and culture diversity. Jurnal Minds: Manajemen Ide dan Inspirasi, 8(1), 01-14. https:// doi.org/10.24252/minds.v8i1.19316.

Kahya, E. (2009). The effects of job performance on effectiveness. International Journal of Industrial Ergonomics, 39(1), 96-104. https:// doi.org/10.1016/j.ergon.2008.06.006.

Kithae, D. P., \& Keino, D. C. (2016). Effects of work life balance on staff performance in the telecommunication sector in Kenya. Archives of Business Research, 4(1), 129-138. https:// doi.org/10.14738/abr.41.1747.

Laksono, B. F., \& Wardoyo, P. (2019). Effect of work - life balance, job satisfaction and work engagement on turnover with intentions mentoring as a moderating variables in employees Hotel Dafam Semarang. Jurnal Riset Ekonomi dan Bisnis, 12(1), 17-36. https://doi.org/10.26623/jreb.v12i3.1758.

Liu, D., Mitchell, T., Lee, T., Holtom, B., \& Hinkin, T. (2012). When employees are out of step with coworkers: How job satisfaction trajectory and dispersion influence individual-and unit-level voluntary turnover. Academy of Management Journal, 55(6), 1360-1380. https://doi.org/10.5465/amj.2010.0920. 
Locke, E. A. (1969). What is job satisfaction?. Organizational Behavior and Human Performance, 4(4), 309-336. https:/ / doi.org/10.1016/0030-5073(69)90013-0.

Locke, E. A. (1970). Job satisfaction and job performance: A theoretical analysis. Organizational Behavior and Human Performance, 5(5), 484-500. https:/ / doi.org/10.1016/0030-5073(70)90036-X.

Malik, M., Wan, D., Dar, L., Akbar, A., \& Naseem, M. A. (2014). The role of work life balance in job satisfaction and job benefit. Journal of Applied Business Research, 30(6), 1627-1638. https:/ / doi.org/10.19030/jabr.v30i6.8879.

Martensen, A., \& Grønholdt, L. (2006). Internal marketing: A study of employee loyalty, its determinants and consequences. Innovative Marketing, 2(4), 92116.

Maroofi, F., \& Navidinya, F. (2011). The measurement of job performance and its impact on effectiveness. International Journal of Business Performance Management, 12(3), 217-227. https:/ / doi.org/10.1504/IJBPM.2011.039887.

Mendis, M. D., \& Weerakkody, W. A. (2017). The impact of work life balance on employee performance with reference to telecommunication industry in Sri Lanka: A mediation model. Kelaniya Journal of Human Resource Management, 12(1), 72-100. https:/ / doi.org/http:/ / doi.org/10.4038/kjhrm.v12i1.42.

Metin, K., \& Asli, K. (2018). The relationship between organizational commitment and work performance: A case of industrial enterprises. Journal of Economic and Social Development, 5(1), 46-50.

Murphy, K. R. (2008). Perspectives on the relationship between job performance and ratings of job performance. Industrial and Organizational Psychology, 1(2), 197-205. https:/ / doi.org/10.1111/j.1754-9434.2008.00039.x.

Ötken, A. B., \& Erben, G. S. (2013). The relationship between work-life balance and happiness from the perspectives of generation $X$ and Y. Philippine Social Sciences and Humanities Review, 2(4), 45-53.

Park, C. (2020). Inter-organizational relationships management as a knowledge strategy: A simulation approach. Dynamic Relationships Management Journal, 9(2), 5-18. https:// doi.org/10.17708/DRMJ.2020.v09n02a01.

Poelmans, S., \& Caligiuri, P. (2008). Harmonizing work, family and personal life: From policy to practice. Cambridge: Cambridge University Press.

Poelman, E. H., Galiart, R. J., Raaijmakers, C. E., Loon, J. J., \& Dam, N. M. (2008). Performance of specialist and generalist herbivores feeding on cabbage cultivars is not explained by glucosinolate profiles. Entomologia Experimentalis et Applicata, 127(3), 218-228. https://doi.org/10.1111/j.15707458.2008.00700.x.

Podsakoff, P. M., Mackenzie, S. B., Paine, J. B., \& Bachrach, D. G. (2000). Organizational citizenship behaviors: a critical review of the theoretical and empirical literature and suggestions for future research. Journal of Management, 26(3), 513-563. https://doi.org/10.1016/S0149-2063(00)000477.

Preko, A. K., \& Adjetey, J. (2013). A study on the concept of employee loyalty and engagement on the performance of sales executives of commercial 
banks in Ghana. International Journal of Business Research and Management, 4(2), 51-62. https:// doi.org/10.1.1.741.1639.

Pritchard, R. D., Jones, S. D., Roth, P. L., Stuebing, K. K., \& Ekeberg, S. E. (1988). The effects of feedback, goal setting, and incentives on organizational productivity. Journal of Applied Psychology Monograph Series, 73(2), 337-358. https:/ / doi.org/10.1037/0021-9010.73.2.337.

Ratnasari, S. L., Sutjahjo, G., \& Adam, A. (2020). The effect of job satisfaction, organizational culture, and leadership on employee performance. Annals of Tropical Medicine $\mathcal{E}$ Public Health, 23(13A), SP231329. http:// doi.org/10.36295/ ASRO.2020.231329.

Rajput, S., Mayank, S., \& Shivkant, T. (2016). Job satisfaction and employee loyalty: A study of academicians. Asian Journal of Management, 7(2), 105-109. https:/ / doi.org/10.5958/2321-5763.2016.00015.9.

Rincy, V. M., \& Panchanatham, N. (2014). Work life balance: A short review of the theoretical and contemporary concepts. Continental Journal Social Sciences, 7(1), 01-24. https:/ / doi.org/10.5707/cjsocsci.2014.7.1.1.24.

Schuler, R. S. (1989). Strategic human resource management and industrial relations. Human Relations, 42(2), 157-184. https:// doi.org/10.1177/001872678904200204.

Shore, T. H., Thornton, G. C., \& Shore, L. M. (1990). Construct validity of two categories of assessment center dimension ratings. Personnel Psychology, 43(1), 101-116. https://doi.org/10.1111/j.1744-6570.1990.tb02008.x.

Stanton, J. M., Stam, K. R., Guzman, I. R., \& Caledra, C. (2003). Examining the linkage between organizational commitment and information security. Conference: Systems, Man, and Cybernetics, 2003. IEEE International Conference, 3, 01-06. https:/ / doi.org/10.1109/ICSMC.2003.1244259.

Syarif, A. F., Basuki, P. N., \& Wijaya, A. F. (2017). Information system performance analysis at PT Central Bank Asia Using the IT balanced scorecard. Jurnal Nasional Teknik Elektro dan Teknologi Informasi, 7(1), 01-06. https:// doi.org/10.22146/jnteti.v7i1.393.

Terek, E., Mitić, S., Cvetkoska, V., Vukonjanski, J., \& Nikolić, M. (2018). The influence of information technology on job satisfaction and organizational commitment. Dynamic Relationships Management Journal, 7(2), 39-49. https:/ / doi.org/10.17708/DRMJ.2018.v07n02a04.

Vroom, V. H. (1964). Work and motivation. New Jersey: Wiley.

Westman, M., Brough, P., \& Kalliath, T. (2009). Expert commentary on work-life balance and crossover of emotions and experiences: Theoretical and practice advancements. Journal of Organizational Behavior, 30(5), 587-595. https:// doi.org/10.1002/job.v30:510.1002/job.616.

Wijayanti, T. C., Setini, M., Darma, D. C., Purwadi, P., \& Alka, P. R. (2020). Connectivity continuous improvement program and employee performance. International Review of Management and Marketing, 10(1), 54-62. https://doi.org/10.32479/irmm.9161.

Živčicová, E., Bulková, K., \& Masárová, T. (2017). Comparison of the selected indicators of work life balance in European Union Countries. Economics and 
Sociology, 10(1), 222-231. https://doi.org/10.14254/2071-789X.2017/10$1 / 16$.

Zimmerman, R. D., \& Darnold, T. C. (2009). The impact of job performance on employee turnover intentions and the voluntary turnover process: A metaanalysis and path model. Personnel Review, 38(2), 142-158. https:// doi.org/10.1108/00483480910931316. 